\title{
The Political Economy of Trade Union Strategies in Austria and Germany: The Case of Call Centres
}

\begin{abstract}
This article offers a systematic comparison of strategic responses of Austrian and German unions to an emergent sector. It aims to increase understanding of both union movements, and also to contribute conceptually to the study of the varieties of unionism. The concept of 'core strategies' facilitates more systematic comparisons of unions' strategic responses to apparently similar challenges and helps explain why - despite many similarities in their industrial relations systems and the uniform development of the call centre sector in both countries - the strategic responses of Austrian and German unions differ remarkably in terms of content, priority and timing. KEYWORDS: Austria - call centres - Germany - industrial relations - trade union strategies
\end{abstract}

\section{Introduction}

The core of both Austrian and German industrial relations is the dual system of interest representation based on a division of work between unions and works councils (Jacobi et al., 1998; Traxler, 1998). Germany and Austria are thus typically treated as two 'most similar cases'; ${ }^{1}$ yet systematic comparisons between them, in terms of the industrial relations systems or varieties of unionism, are rare (for an exception see the contributions in Endruweit et al., 1985). This article, by contrast, points to key differences in the logics underlying Austrian and German unionism.

Though trade unions in most Western European countries are currently facing similar political, economic and social challenges, very little systematic comparative research on their strategic responses has been undertaken. The emergent call centre sector is closely associated with several of the current challenges to unions in advanced capitalist countries: vertical disintegration of large companies, increased outsourcing, a structural shift from manufacturing to services, and the growing significance of atypical 
employment. Thus, the call centre sector poses a litmus test to the logics underlying current Austrian and German unionism.

To facilitate systematic comparison, this article introduces the concept of union core strategies. Mapping the variegated impact of apparently similar challenges on unions' strategic capacities within and across countries helps 'contextualize' the comparison and avoid the pitfalls of comparing 'apples and oranges' (Locke and Thelen, 1995; Schregle, 1981). This enables us to understand both the intra-country and the cross-country variations in unions' strategic responses in terms of their content, intraunion priority and timing.

The call centre sector emerged in a similar fashion in both countries, with a reconfiguration of established sector and market boundaries. Today, three types of call centres exist: internal, spin-off and subcontracting (Batt et al., 2005; Holtgrewe, 2005; Schönauer, 2005). Internal call centres are the classic type: organizational units within companies. Spinoff call centres are mostly former internal centres which still limit their activities to the parent company. Subcontracting call centres operate as outsourcing partners for various clients.

To capture the specific logic of sector formation, the strategic responses of German and Austrian unions are analysed and systematically compared across three key segments (mail order business, telecommunications and subcontracting call centres) and over time in three periods (sector establishment, sector expansion and sector consolidation), each characterized by specific competitive relations between the different segments. ${ }^{2}$ This increases the number of observations (nine in each case) as well as the generalizability of the empirical findings (Landman, 2004).

The article derives from research within the NODE-project (New Orientations for Democracy in Europe) of the Austrian Federal Ministry for Science and Research. The primary sources are 18 structured interviews the author conducted with union officials in both countries, covering three themes: problem perception, internal strategies and external strategies. The unions concerned were ver.di (Vereinte Dienstleistungsgewerkschaft), its predecessors HBV (Handel, Banken und Versicherungen), DPG (Deutsche Postgewerkschaft) and DAG (Deutsche Angestellten-Gewerkschaft ${ }^{3}$ as well as the peak confederation DGB (Deutscher Gewerkschaftsbund) in Germany; and GPA (Gewerkschaft der Privatangestellten) and the peak confederation ÖGB (Österreichischer Gewerkschaftsbund) in Austria. In addition, the author conducted five interviews with representatives from business associations and other sector experts. These interviews are not systematically exploited but rather used as background information on the process of sector formation. Union journals and internal union documents were analysed. The two professional journals of the Germanspeaking call centre sectors, Callcenter profi and teletalk, contained helpful background information. 


\section{Trade Unions as Strategic Organizations: Core Strategies of Austrian and German Trade Unions}

Trade unions in advanced capitalist countries currently face similar challenges: employers' demands for increasing flexibility, the shift from manufacturing to private services, growing unemployment, the decline of corporatism. Under the influence of the 'new institutionalism', most analyses of the strategic responses of trade unions to these challenges concentrate on the institutional configuration of the industrial relations system or the national capitalist model as explanatory factors (Hall and Soskice, 2001; Thelen, 2002). But though institutions endow trade unions with specific capacities they do not prescribe their behaviour. Empirical research has shown that the strategic responses of trade unions across countries to apparently similar challenges differ not only in terms of their content but in terms of their intra-union priorities and their timing (Clegg, 1976; Martin and Ross, 1999; Turner, 1991). In order to understand the logics of these strategic responses we therefore cannot restrict ourselves to studying what unions do, we have to analyze what they do not do. Why do unions address certain issues but ignore others? Why do they prioritize certain challenges over others?

As Locke and Thelen argue (1995: 359), 'seemingly different, nationally specific conflicts are in fact analytically analogous', and vice versa. The difference in meaning of apparently similar challenges is explained by referring to the specific identities of historically existing trade unions: they assign a higher priority to a challenge if it conflicts with their established identity. However, Hyman (2001a: 219f.) correctly stresses that Locke and Thelen's causal explanation suffers from 'an implicit circularity'. Unions' identities are themselves subject to change, they are not fixed but fluid and internally as well as externally contested (see Hyman, 2001b). Potentially, an organization has at least as many identities as members.

In order to avoid these pitfalls and to facilitate meaningful comparison of the logics underlying different unionisms, I introduce the concept of union core strategies. This builds on insights from organizational sociology, and aims to conceptualize the variegated impact of apparently similar challenges on the strategic capacities of trade unions across countries. The core strategies fulfil a crucial function for unions since trade unions are 'universally organizations for the representation of interests' (Hyman, 1996: 55). They are thus the central means by which unions seek to prove their specific claim to representativeness, whether its scope is class, region, industry or company (see Streeck, 1993).

Note that my use of the notion of 'strategy' departs from its common use in sociology and game theory, where it is typically associated with conscious, rational decisions based on an instrumental and a long-term perspective (Crow, 1989). Though unions pursue instrumental goals 
(the representation of the interests of their constituencies), the content of union strategy is deeply embedded in habitual and routine practices. Sociologically, union organizations are not uniform actors, and their strategic responses are the product of social processes consisting of reproductive and transformative behaviour by individual members of the organizations who are enabled and constrained by formal organization structures and norms of 'appropriate' behaviour.

Since their core strategies are the very means to prove their claim of representing workers' interests, unions are sensitive to developments impairing their capacities to pursue their core strategies successfully. Therefore, the central assumption is that the more a challenge impairs a union's capacities to pursue its core strategies successfully, the higher the priority it assigns to addressing the challenge. Under conditions of scarce resources, a higher intra-union priority means more resources are devoted to the challenge. Changes in an organization's environment are by definition ambiguous; they require interpretation (March and Olsen, 1994). Therefore, organizations permanently monitor and evaluate the impact of their own actions on their environment (Argyris and Schön, 1978; Hedberg, 1981). Sociologically, union organizations are not uniform actors. A union's pursuit of its core strategies is the outcome of coordinated behaviour of its individual members being enabled and constrained by formal organization structures, intra-organization politics and norms of 'appropriate' behaviour.

Whether union organizations respond to challenges by reproducing or by revising their core strategies is the outcome of potential internal conflicts, and thus an empirical question. Note that even radical 'revitalization' efforts such as the introduction of the organizing-model by American trade unions can be analytically understood as the strategic responses of bureaucratic organizations to the specific crisis of the union organization, involving a perception that established core strategies are exhausted. Below, the concept of union core strategies is applied in an attempt to understand the strategic behaviour of unions as organizations and therefore to 'contextualize' the cross-country comparison of unions' strategic responses to the emergence of the call centre sector. It will be shown that German and Austrian unions formally pursue the same core strategies: negotiating sectoral agreements. However, their strategic capacities to pursue these core strategies are contingent upon different foundations in both countries, and thus vulnerable to different developments.

\section{Union Core Strategies in Austria and Germany}

Austria and Germany are known as the prototypes of the so-called 'dual system' of interest representation. Collective bargaining at sectoral level 
is the exclusive domain of trade unions (Tarifantonomie), while works councils possess a separate range of competences at company level. Despite their formal mutual independence, a symbiotic relationship between works councils and trade unions developed in both countries (Schmidt and Trinczek, 1999). Additionally, current trends towards greater flexibility point in the same direction: Austrian and German unions both have been pushed and pulled to relocate competencies to the firm-level and to strengthen the influence of works councils (Baethge and Wolf, 1995).

While trade unions pursue similar core strategies, the conditions for successful strategic action differ in both countries. This argument can be illustrated by differences in the outcomes of collective bargaining. First, bargaining coverage in Austria is significantly higher and more stable than in Germany. In Austria the coverage of collective agreements is still virtually universal (more than 95 percent), but in Germany it has declined to roughly two-thirds. Second, despite the encompassing scope of collective agreements, wage dispersion both in terms of contractual and real wages throughout the post-war period has been significantly higher in Austria than in Germany (Wallerstein, 1999; OECD, 2004).

Both differences can be traced back to the distinctive corporatist tradition in Austria, with obligatory membership of employers in the Wirtschaftskammer Österreich (WKÖ). Since firms cannot leave the employers' association in order to bypass existing collective agreements, the erosion of the system of sectoral agreements is institutionally prevented; hence while German unions are mainly fighting defensive struggles, Austrian unions have been successful in achieving agreements for new economic sectors (Hermann and Flecker, 2006). The greater wage dispersion in Austria is the result of 'pattern bargaining' oriented towards general economic goals such as productivity growth and employment security (Rosner, 1999; Traxler, 2001); wage equality was never high on the union agenda. Furthermore, the industrial unionism principle is much less dominant: the peak association (ÖGB) enjoys considerable power over its affiliates, while a powerful white-collar affiliate (GPA) exists alongside blue-collar unions. Although the unions cooperate closely, manual and white-collar workers in most companies are subject to two different collective agreements signed by different unions. By pursuing a productivity-oriented bargaining strategy based on wage restraint, Austrian unions contribute to the legitimacy of the encompassing nature of collective agreements. In Germany the outcomes of collective bargaining are to a great extent determined by intra-sector dynamics such as worker mobilization and economic growth (Bispinck, 1993).

To summarize, the core strategies of both Austrian and German unions involve negotiating industry agreements. However, in Austria this is at least partly a politico-administrative process, while in Germany 
it is a purely industrial endeavour. In Germany collective bargaining is almost exclusively dependent on intra-sectoral contingencies: economic conditions and unions' capacities to mobilize core workers for industrial action. Austrian unions are less dependent on the support of core workers. The bargaining process is to a certain extent autonomous from intra-sector developments and more contingent on general political-economic dynamics. These differences have an impact on the particular vulnerabilities of union core strategies, hence we can expect unions in both countries to react differently to similar political-economic challenges associated with the development of the call centre field.

\section{The Formation of the Call Centre Sector in Austria and Germany}

In both Austria and Germany, data on the emerging call centre field are scarce since it is not yet covered by official statistics. According to recent estimates, in Germany there are currently some 5000 call centres, employing 330,000 workers (DDV, 2005; Holtgrewe, 2005); while in Austria there are 400 to 500, employing 30,000 workers (Schönauer, 2005). ${ }^{4}$ Thus in both countries, call centres account for roughly one percent of total employment. The similar relative size of the sector in both countries facilitates meaningful comparison.

The following section discusses the historical development of the sector in Austria and Germany; the focus is on the competitive relations between organizations. The potential challenges to trade unions' strategic capacities are mapped by applying a market-sociological approach inspired by the new economic sociology (Bourdieu, 2005; Dobbin, 2004). Since outsourcing to subcontracting call centres is an important driving force in the process of sector formation, it is important to distinguish two dimensions of competition: first between internal and subcontracting call centres, and second among subcontractors for clients. ${ }^{5}$ Note that the first dimension of competition constitutes a particular challenge to Austrian and German unions since it crosses the boundaries of established sectors as bargaining domains. Three parallel periods of sector formation can be identified in both countries, each characterized by specific competitive relations within the sector: establishment, expansion and consolidation.

The establishment period of the call centre sector started in both countries with the introduction of ACD (Automatic Call Distribution) technology in 1990. Internal call centres were the dominant type during the early years. The overall growth rates were limited and employment effects were small. In 1995, fewer than 50,000 workers were employed in German call centres (DDV, 2005); employment in Austrian call centres was equally marginal (Böhm et al., 1999). Consequently, competition had a 
rather low intensity on both dimensions. There was neither intense pricecompetition between internal and subcontracting call centres nor amongst subcontractors. Thus, there were few pressures on wages.

The development of the call centre sector changed its dynamic in both countries during the expansion period from the second half of the 1990s (Holtgrewe, 2005; Schönauer, 2005). Growth rates accelerated particularly around the millennium. Three factors triggered rapid expansion: first, the introduction of CTI (Computer Telephony Integration) technology; second, the political liberalization of telecommunications; and third, a shift in corporate governance stressing flexibility and cost reduction. Outsourcing of repetitive, simple call centre services grew rapidly in volume as a means to externalize pressures for flexibility and cost reduction (Holtgrewe and Kerst, 2002). The expansion of the emerging call centre sector was mainly an expansion of the segment of subcontracting call centres which significantly increased the share of subcontractors within the total. Competition intensified in both dimensions: between internal and subcontracting call centres in sectors such as telecommunications, retail, finance and tourism as well as among subcontractors. Moreover, competition was mainly (labour) cost-oriented which placed considerable pressure on wages in both internal and subcontracting call centres.

Consolidation followed a short but severe crisis, with numerous bankruptcies of subcontractors in 2001-2 in Germany and 2002-3 in Austria. Growth rates declined but remained stable at a moderate level. Subcontractors aim at establishing stable, long-term relationships to their clients. Particularly in telecommunications but in other sectors as well relatively stable production networks evolved, consisting of internal call centres and various subcontractors. After outsourcing of simple and repetitive services, the remaining internal call centres produce highquality services or deal with sensitive information. Additional outsourcing concerns more complex and thus trust-dependent services (business process outsourcing) and new sectors such as pharmaceuticals or energy. Thereby, the competitive relations between internal and subcontracting call centres changed their focus to quality, so that labour costs were no longer the most important determinants of competition, thus reducing the pressure on wages in the remaining internal call centres. At the same time, competition among subcontractors was still mostly cost-oriented, leading to continuous pressures on wages in subcontractors.

\section{Union Strategies towards Call Centres in Germany}

\section{Sector Establishment (Up to 1995)}

In general, German unions assigned a very low priority during the early 1990 s to call centres in the mail order business and in telecommunications. 
Neither HBV nor DPG pursued a distinct call centre strategy, nor did they dedicate significant resources to unionizing activities. Call centres did not seem to threaten the strategic capacities of either union. While HBV's strategic response in retail can be classified as 'tacit acceptance', DPG's response in telecommunications resembled 'business as usual'.

In terms of collective bargaining the German mail order business is part of the retail sector. Here, in contrast to other sectors, subcontracting and spin-offs were quite common in the early 1990s. The joint venture between one of Germany's largest telemarketing companies and a subsidiary of a leading mail order company can serve as an example. The parent company outsourced its order hotline in 1993 to a new company which did not join the employers' association so as to evade the retail sector agreement. The new company not only paid lower wages but resorted to freelance work to increase flexibility and reduce labour costs. It is significant to note that the new company later became one of the largest subcontractors in Germany.

Although outsourcing to subcontractors was prevalent in the mail order business, call centres received a low intra-union priority in HBV's retail domain since the mail order business only represented some five percent of the retail sector. Therefore outsourcing did not significantly change the competitive relationship within the union's bargaining domain or weaken its strategic capacities in collective bargaining in retail. On the contrary, since outsourcing prevented core workforces from unpopular night and weekend shifts (Holtgrewe and Kerst, 2002) it may have helped to stabilize the sector agreement.

The situation in telecommunications was different. Until 1996 the sector was dominated by a public enterprise. Thanks to its close ties with the staff councils (Personalräte), DPG managed to exercise considerable influence on the local work organization in the newly established internal call centres. Although some atypical employment, with the risk of turning precarious, existed even within the confines of the public enterprise, internal call centres did not have a high priority for DPG. The union's aim was to prevent new work organization and technology from having negative effects on workers. This goal could be achieved without unionizing the call centre workers. DPG included 'qualitative' issues in collective bargaining such as VDU work and performance control.

\section{Expansion Period (1996-2001)}

The situation changed during the expansion period. In particular, the DPG responded to the changing competitive relations in its main domain, the telecommunications sector, by significantly increasing the priority of 
call centres. The union aimed at organizing workers in internal and subcontracting call centres to regain lost strategic capacities. In contrast, HBV continued its passive stance towards call centres in the mail order business.

The deep segmentation in the telecommunications sector between the former monopolist Deutsche Telekom (DT) and new rival companies was reflected in a similar split in the strategies pursued by DPG. The union continued its consultation strategy with works councils in highly unionized DT companies in order to influence the implementation of new call centre technology at local level. Simultaneously, DPG implemented resource-intensive unionizing projects in the new rival telecommunication companies. The intense price competition between subcontracting and internal call centres resulted in strong pressures on wages in internal call centres. DPG's strategic capacities in collective bargaining at DT were severely impaired.

Recruiting workers in the new companies thus became a strategic imperative. In 1999, DPG launched an organizing project and spent considerable resources on organizing workers in internal and subcontracting call centres. The project involved a three-step strategy: establishing works councils, negotiating company agreements with market leaders, and concluding a sector agreement for subcontractors to prevent 'social dumping' (Dürotin, 1999). However, the project did not restore DPG's strategic capacities since the union failed to recruit a significant number of workers. In the light of its low organizational basis, DPG and later ver.di had to revert to negotiating compensation plans and transition periods when confronted with outsourcing.

While call centres in the telecommunications sector enjoyed a significant increase in intra-union priority during the expansion period, the priority of call centres in the mail order business remained low. HBV and DAG did not dedicate significant resources to call centres in the mail order business nor did they pursue a distinct organizing strategy. Despite the passive approach of both unions, they finalized a company agreement on call centres in the mail order business with one of the largest German mail order companies. However, the agreement was an outcome of union weakness rather than strength: the management threatened to outsource all of its internal call centres if the unions did not agree to an agreement that adjusted the sector agreement in retail to meet its needs. Because of the lack of membership the unions' strategic capacities in the negotiations were weak; thus by agreeing to concession bargaining HBV and DAG managed to stabilize the sectoral agreement in retail. After the union merger in 2001, ver.di even managed to extend the company agreement to a regional sectoral agreement for call centres in retail. It attempted to prevent cost competition between internal and subcontracting call centres in retail by extending the agreement to subcontractors operating in retail, 
but because of the lack of membership of subcontracting call centres in the employer association this was unsuccessful.

\section{Consolidation (since 2002)}

While call centres attracted greater intra-union priority during the expansion period, in the consolidation period ver.di stopped dedicating significant resources to unionizing them and assumed a rather passive role. The altered competitive relationship between internal and subcontracting call centres, particularly in telecommunications, eased the pressures on ver.di's strategic capacities.

In telecommunications, ver.di continued its technological consultation policy in DT companies, but because of severe financial difficulties stopped its (mostly unsuccessful) unionizing efforts with subcontractors. The union's strategic capacities in call centres in both segments of telecommunications were limited by low membership. DT management has recently announced plans to restructure its internal call centres in order to reduce labour costs. Furthermore, low wages in subcontractors are used by management to pressure unions into accepting lower wages in DT call centres. This may oblige ver.di to give higher priority to call centres; but at the time of writing, the outcome remains uncertain.

As in previous periods, call centres in the mail order business enjoyed a low intra-union priority. The regional sectoral agreement mentioned above still formally exists but has become rather hollow. Employers in retail frequently hive-off their call centres and the new companies do not join the regional employers' association. In practice, the sectoral agreement is no more than a single-company agreement.

The union merger in 2001 changed the unions' organization structures for subcontractors. In general, it strengthened the sectoral logic (Keller, 2004). From 2001, subcontractors have become a distinct union domain within the department of 'miscellaneous services', hence they are organizationally separated from in-house call centres. Not surprisingly, ver.di's goal is to negotiate a sectoral agreement for subcontractors; but financial resources for unionizing subcontractors are small. The combination of low membership and the union's financial crisis means that its strategic capacities are limited. It cannot redistribute resources internally, a necessary precondition for organizing a previously non-unionized field. Despite these problems the union has managed to finalize a framework agreement (Rabmentarifvertrag) with one of the leading subcontracting companies, Walter Telemedien. The central component of the agreement is an annualized work-time record which serves the interests of both employers and workers. However, further success is unlikely without upgrading the intra-union priority of call centres and the allocation of new resources to organizing efforts. 


\section{Union Strategies towards Call Centres in Austria}

\section{Sector Establishment (Up to 1997)}

The strategic responses from Austrian unions have been remarkably different. Call centres fell exclusively into the domain of the white-collar union GPA. In general, the union responded proactively to the emergence of call centres and assigned medium priorities to all three segments of the call centre field during the early stages of field formation.

GPA was confronted with subcontractors as early as 1996. Following the procedures of Austrian social partnership, the government invited the GPA and the WKÖ to approve an exemption for call centres from the prohibition of weekend and holiday work. The request for exemption was filed by a German subcontractor planning to open a branch in Salzburg (Böhm et al., 1999). GPA initially refused, making its consent contingent on the establishment of a works council in the new company and the general incorporation of subcontractors into the system of collective agreements; but in March 1997 the government issued the exemption.

Simultaneously, GPA had begun negotiations with its bargaining counterpart over the incorporation of subcontractors into the encompassing system of collective agreements (Böhm et al., 1999). Both GPA and the employers' association lacked experience with call centres. Therefore a representative of the German subcontractor participated in the negotiations and its Austrian branch later became one of the first subcontractors in Austria. In rather bureaucratic fashion the bargaining partners agreed to incorporate those call centres not covered by other sectoral agreements into the agreement for miscellaneous business (Allgemeines Gewerbe). Thus, since 1998 Austrian subcontractors have been covered by a collective agreement.

GPA pursued a similar proactive bargaining strategy in the liberalized telecommunications sector. With the postal union for the public service sector it negotiated in 1998 a collective agreement for the so-called 'alternative' telecommunication companies. This extended central provisions of the agreement for the former state monopoly Telekom Austria (TA), such as wages, weekly work time and wage groupings, to the new rival companies. The agreement covered both the rivals of TA and its subsidiaries, and thus most internal call centres in the telecommunications sector. The union exerted successful political pressure for a legal regulation preventing companies controlled or owned (more than 50 percent) by TA to depart from the telecommunication agreements. In other sectors, unions had no means of impeding spin-offs to switch to a 'cheaper' collective agreement. Companies were automatically subsumed into a collective agreement according to their affiliation to one of the subunits of WKÖ. 
Similar strategies were pursued by GPA in the mail order business. As in Germany, this is an important sector for subcontracting call centres. In 1999 GPA and WKÖ signed a collective agreement for these call centres based on the collective agreement for retail. GPA hoped to prevent outsourcing by adjusting the sector agreement in retail to the specific needs of call centres (GPA, 1999). However, the agreement was largely a formality since it does not cover smaller firms.

\section{Expansion Period (1998-2002)}

GPA's strategic response to the expansion of the call centre field has been remarkably consistent, re-negotiating annually the sectoral agreements. While intra-union priority of German call centres increased during the expansion period because of intense competition between internal and subcontracting call centres, similar competitive relations did not cause GPA to increase the priority of call centres in a similar manner.

In Austria, the establishment of several new telecommunications companies and the subsequent growth of this sector occurred against the backdrop of a pre-existing sectoral agreement. This was re-negotiated annually, with wage increases linked to general productivity trends. Recruiting workers in the telecommunications call centres was not a union priority: GPA's strategic capacities in collective bargaining were not impaired by either increased outsourcing or subsequent cost competition between internal and subcontracting call centres. The topics that featured prominently on the bargaining agenda were flexible working time and technological change. GPA cooperated closely with unionized works councils to influence the implementation of technological change at workplace level (Angerler, 1999). The long-term goal of the GPA was to negotiate a unitary sector agreement covering both TA and its rivals, thus simplifying the bargaining process; but two distinct agreements still exist.

Closely intertwined with changes in telecommunications was GPA's strategic response to the expansion of subcontractors. In contrast to German experience, the upsurge of subcontractors in Austria took place within the context of their integration into the encompassing system of collective agreements. Though GPA's long-term goal was to negotiate a specific call centre sector agreement, the employers showed little interest, instead the agreement for Allgemeines Gewerbe was re-negotiated annually. However, wage increases were virtually identical in the various sector agreements, being linked to general productivity growth. The strategic capacities of GPA were not impaired by cost competition between internal and subcontracting call centres, nor did the incorporation of both segments into the encompassing system of collective agreements prevent cost competition between companies. A study of regional call centres in 
Salzburg revealed that particular subcontractors bypassed collective agreements by replacing their regular workforces with self-employed workers in order to reduce labour costs. In 1999, 77 percent of workers in subcontracting firms were self-employed and on a free-lance contract (Böhm et al., 1999). In most companies only the management held a regular employment contract.

The freelance contract (freier Dienstvertrag) is an Austrian peculiarity. It was introduced in 1998 in order to include free-lance workers in the social security system (Pernicka, 2005). However, employers in call centres use it as an intra-plant means to bypass collective agreements, since these only apply to dependent employees. The self-employed are excluded both from collective agreements and from basic labour law provisions such as sick-pay leave and unemployment insurance. Thus, subcontractors using freelance contracts are formally subject to collective agreements, but the majority of their workforce is excluded.

GPA formally protested against these evasion practices and claimed that the use of the freelance contract in call centres is a form of false selfemployment (Angerler, 1999). However, GPA did not assign a high priority to this campaign. In general, dependent self-employed workers received little attention, although GPA reformed its organization structure in 2000 and established a distinct interest group for the representation of their interests. The union's official position was that dependent self-employment in call centres represents illegal, spurious self-employment, and its activities for the self-employed were limited to legal assistance. Therefore, the interests of the dependent self-employed were not incorporated in collective bargaining (Pernicka, 2005). From the perspective of the union the incorporation of subcontractors into the overall system of collective agreements represented a success. However, these agreements did not prevent intense cost competition between internal and subcontracting call centres, and had little influence on work and pay conditions in subcontractors.

\section{Consolidation (since 2003)}

Union strategic responses changed little during the consolidation period, with the annual re-negotiation of the three sectoral agreements. Intraunion priorities also remained unchanged. However, evasion practices in the call centres also continued. Today, more than 70 percent of all subcontractors and 20 percent of all internal call centres in Austria resort to freelance contracts. The importance of these evasion practices is illustrated by the fact that on average employers resorting to these contracts have more than 80 percent of their workforce self-employed (Schönauer, 2005).

Until recently, employers did not encounter a great deal of union resistance. However, in the summer of 2006 GPA started a campaign to 
organize workers in both internal call centres and subcontractors. Together with the social insurance agencies, ${ }^{6}$ GPA pursued a test case challenging the legality of freelance contracts in call centres. This campaign was initiated by the interest group for dependent self-employed workers, which improved its position within the union by contributing to the union's core strategy. Responding to these pressures, some employers favoured negotiations for a specific collective agreement for call centres. However, due to its lack of membership in subcontractors GPA could not force employers into collective bargaining, so a collective agreement for call centres is still not in reach. By the time of writing, union activities in call centres have once again lost momentum.

\section{Conclusions}

Trade unions' strategic responses in Austria and Germany to the emergence of the call centre sector reveal a surprising degree of variation. Despite overall similarities in the industrial relations systems and the emergence of the call centre sector, union responses varied considerably in terms of institutional outcomes, intra-union priorities and timing. The research design facilitated both intra- and cross-country comparison of these responses. Table 1 summarizes the empirical findings. The conclusions will start with intra-country comparisons focusing on what the unions did and did not do. Particular attention will be paid to the impact of the change in competitive relations on the capacities of unions to pursue their core strategies successfully. Subsequently, the results from the research will be used to draw general inferences on Austrian and German trade unionism and industrial relations.

In the Austrian case, there was very little variation across the three periods and between the three segments in intra-union priorities. GPA pursued an active, indeed proactive strategy in all three segments. Particularly striking is the successful incorporation of subcontracting call centres into the encompassing system of collective agreements. As a leading GPA official put it: 'first came the collective agreement, and then came the employees'. GPA and its bargaining counterpart WKÖ negotiated a collective agreement for subcontractors before that segment had significant employment effects. Since then, annual wage increases were negotiated within the framework of 'pattern bargaining', leaving the differences between the agreements virtually unchanged.

Another striking finding in the Austrian case is that during the three periods the variegated competitive relations had no influence on union strategic responses. As noted, wage increases followed general productivity trends, whether or not there was competition between the internal and subcontracting call centres (establishment period), intense price 


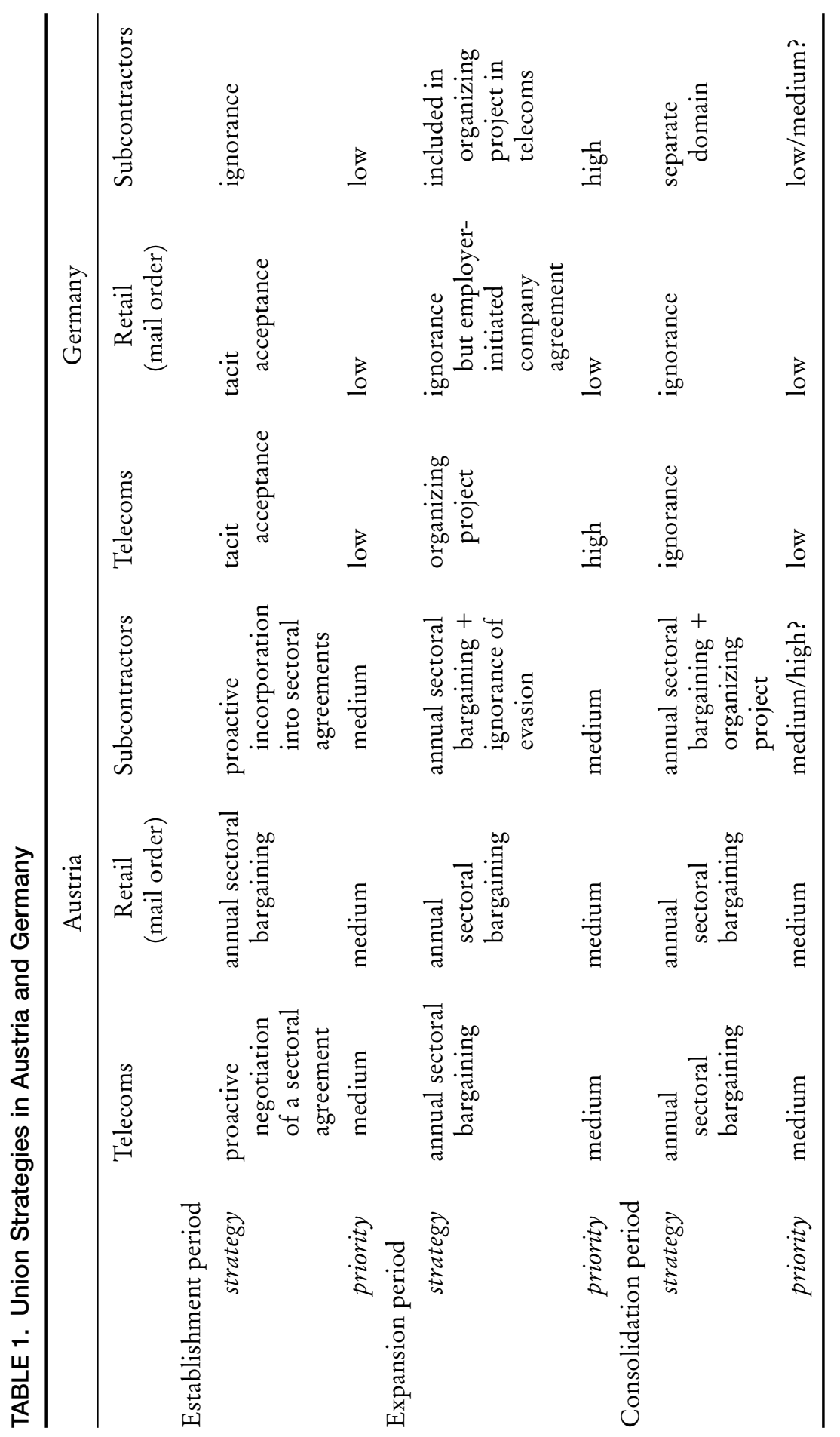


competition both between internal and subcontracting call centres and among subcontractors (expansion period), or quality competition between internal and subcontracting call centres (consolidation period). Note that the wage differences between the agreements were the primary driving force for price competition between internal and subcontracting call centres. Diverse competitive relations within the market had no impact on unions' capacities to pursue their core strategies. Because of the employer's obligatory membership in WKÖ and 'pattern bargaining' the strategic capacities of Austrian unions are institutionally insulated from competitive pressures in the call centre market.

By contrast, in Germany there were marked changes over the three periods and variation between the three segments. Changing strategic responses across the three periods of sector formation can be explained by the altered competitive relations. Unlike the Austrian unions, the German unions did not respond to call centres during the establishment period. In all segments their responses can be classified as ignorance or tacit acceptance. The intra-union priority of call centres did not increase before intense price competition between internal and subcontracting centres impaired unions' capacities to pursue their core strategies. This inference can be drawn from the subsequent diminished priority during the consolidation period when competition among subcontractors began focusing on quality. Thus, the strategic capacities of German unions are particularly vulnerable to competition crossing the boundaries of established bargaining domains.

The variation between the segments is as striking as the changes across periods. While DPG responded to the price competition between internal and subcontracting call centres in telecommunications, HBV did not respond to similar competitive relations within retail. This can be explained by the differing impact of price competition on unions' capacities to pursue their core strategies. DPG's strategic capacities in telecommunications collective bargaining were challenged by employers' demands for downward adjustment of labour costs in internal call centres. In retail, cost competition between internal and subcontracting call centres did not have the same effect on HBV's strategic capacities. Call centres in retail are mainly limited to the segment of the mail order business which itself is only a small fraction of the bargaining domain.

Cross-country comparison reveals that unions in both countries responded to the challenges posed by the emergence of call centres according to the capacities endowed by the industrial relations system and the differing impact of these challenges on unions' capacities to pursue their core strategies. Unions in both countries attempted to regulate the work and pay conditions in call centres with collective agreements. Without doubt, the similar contents of the strategic responses can be linked to the industrial relations institutions in both countries. The Austrian case is an example 
of institutional reproduction: the unions successfully incorporated call centres into the encompassing system of collective agreements. In contrast, the German case is an example of institutional erosion: the industrial relations system is eroding from its margins, with the growing segment of subcontractors but one example of declining bargaining coverage. It is thus remarkable that German unions did not revise their strategies: alternatives were proposed but not adopted. Thus, both success in Austria and failure in Germany reinforced the intra-union status of the core strategies.

Despite their apparently similar content, the core strategies of Austrian and German unions differ remarkably. It is important to note that unions as strategic organizations in both countries responded to the impact of call centres on their capacities to pursue their core strategies rather than to the low pay and poor working conditions found in the subcontracting call centres. Austrian unions did not increase the priority given to call centres when evasion practices in subcontracting led to a worsening of pay and working conditions for call centre workers. Similarly, German unions did not respond to the analogous worsening in retail caused by intensified cost competition.

The differences in the priority and timing of strategic responses can be explained by the differential impact of the emergence of the call centre sector on unions' strategic capacities. These capacities are more closely linked to economic trends within the bargaining domains in Germany than in Austria. German unions need members in the companies to force employers into collective bargaining, Austrian unions do not. Moreover, bargaining outcomes in Germany strongly reflect economic conditions in the sector; but institutional supports and 'pattern bargaining' entail that the strategic capacities of Austrian unions are relatively independent from the membership base and the economic situation of individual bargaining domains. This is reflected in the significantly higher bargaining coverage.

Unions in Austria have higher capacities to bargain collective agreements but they do not necessarily have higher strategic capacities in collective bargaining. The analysis has shown that unions in both countries lacked the means to prevent labour costs from becoming the primary factor of competition between internal and subcontracting call centres during the expansion period. A brief comparison of the current wage differences between the segments confirms this. In both countries, contractual wages are highest in telecommunications: the entry-level contractual wage for full-time work in call centres of TA is 84 percent of the national median net income, compared to 79 percent at DT: the lower wages in Germany are the result of downward pressures of extensive outsourcing. Wages in subcontractors are considerably lower in both countries: the entry-level wage in the Allgemeines Gewerbe agreement is 74 percent of the median net income. In the absence of collective agreements, wages in 
German subcontractors are more dispersed but not generally lower (Holst et al., 2006). However, those with freelance contracts in Austria receive the lowest income, and are not covered by sickness or holiday pay. Thus, evidence suggests that wage dispersion in call centres is higher in Austria than in Germany, despite the higher formal bargaining coverage.

Trade unions in both countries negotiate collective agreements as their core strategies; but collective agreements have different politicaleconomic meanings in Austria and Germany. The negotiation process has a politico-administrative character in Austria while in Germany its character is essentially industrial. Sectoral agreements were considered to be one of the central components of the German model because they forced employers into 'diversified quality production'; Austrian collective agreements had and still have a smaller impact on companies' production strategies. Wage restraint in the form of relatively high wage differentiation across and within sectors is a central component of pattern bargaining in Austria. Compared to their German neighbours, Austrian unions exchange the institutional support of their capacities to bargain collective agreements with consensual restraint in wage bargaining.

\section{ACKNOWLEDGEMENTS}

The author thanks the Austrian Ministry for Education, Science and Culture for financial support. Thanks also (in alphabetical order) to Georg Adam, Andreas Aust, Jennifer Olson, Helmut Voelzkow and Björn Wagner for comments on an earlier draft. An earlier version of the article was presented at the 2006 SASE conference in Trier.

\section{NOTES}

1 Though political scientists have stressed the differences, describing Austria as a far more corporatist country than Germany (Lehmbruch and Schmitter, 1982).

2 Many call centres operate simultaneously in several segments; thus the segments are overlapping. For analytical purposes, however, we can treat them as distinct units of analysis.

3 ver.di was formed in 2001 through the merger of four DGB affiliates, two of which - the banking and commercial union HBV and the postal workers' union DPG - covered the call centre sector, with the independent white-collar confederation DAG.

4 Similar estimates are given by Datamonitor (2002a, 2002b).

5 A similar distinction was made by Weber (1980), who analysed markets in terms of the social relationship between exchange partners ('interest struggle') and the relationship among competitors ('competition struggle').

Contemporary economics usually refers to the first dimension of competition as the 'make or buy' decision (Williamson, 1975). 
6 These were concerned because employer contributions to the social security systems are significantly lower for all forms of self-employment than for standard forms of dependent employment.

\section{REFERENCES}

Angerler, E. (1999) Arbeit in Call Centers. Vorschläge zur Gestaltung. Wien. GPA.

Argyris, C. and Schön, D.A. (1978) Organizational Learning: A Theory of Action Perspective. Reading, MA: Addison-Wesley.

Baethge, M. and Wolf, H. (1995) 'Continuity and Change in the "German Model” of Industrial Relations', in R. Locke, T. Kochan and M. Piore (eds) Employment Relations in a Changing World Economy, pp. 231-62. Cambridge, MA: MIT Press.

Batt, R., Doellgast, V. and Kwon, H. (2005) U.S. Call Center Industry Report. Strategy, HR Practices \& Performance, Working Paper 05-06, Cornell School of Industrial and Labor Relations.

Bispinck, R. (1993) 'Deutschland', in R. Bispinck and W. Lecher (eds) Tarifpolitik und Tarifsysteme in Europa. Ein Handbuch über 14 Länder und europäische Kollektivverhandlungen, pp. 48-79. Cologne: Bund-Verlag.

Böhm, R., Buchinger, B., Gödl, D. and Gschwandtner, U. (1999) Call-Centers in Salzburg. Telefonieren bis die Obren glühen!, Salzburg: AK.

Bourdieu, P. (2005) 'Principles of Economic Anthropology', in N.J. Smelser and R. Swedberg (eds) The Handbook of Economic Sociology, pp. 75-89. Princeton, NJ: Princeton University Press.

Clegg, H. (1976) Trade Unionism under Collective Bargaining: A Theory Based on Comparisons of Six Countries. Oxford: Blackwell.

Crow, G. (1989) 'The Use of the Concept of "Strategy" in Recent Sociological Literature', Sociology 23(1): 1-24.

Datamonitor (2002a) Austria - Call Centers. Industry Profile. London: Datamonitor.

Datamonitor (2002b) Germany - Call Centers. Industry Profile. London: Datamonitor.

Dobbin, F. (ed.) (2004) The New Economic Sociology. A Reader. Princeton, NJ: Princeton University Press.

DDV (2005) Wirtschaftszahlen im Bereich Direktmarketing/Telefonmarketing, November.

Dürotin, O. (1999) 'Call Center in der Telekommunikationsbranche. Arbeitsbedingungen im Schraubstock', Gewerkschaftliche Praxis 1-2: 13-14.

Endruweit, G., Gaugler, E., Staehle, W.H. and Wilpert, B. (1985) Handbuch der Arbeitsbeziehungen. Deutschland - Österreich - Schweiz. Berlin: De Gruyter. GPA (1999) 'KV in Call-Centern', Kompetenz 5: 30.

Hall, P. and Soskice, D. (eds) (2001) Varieties of Capitalism: The Institutional Foundations of Comparative Advantage. Oxford: Oxford University Press.

Hedberg, B. (1981) 'How Organizations Learn and Unlearn', in P.C. Nystrom and W.H. Starbuck (eds) Handbook of Organizational Design, pp. 3-27. Oxford: Oxford University Press.

Hermann, C. and Flecker, J. (2006) 'Neue Flächentarifverträge in neuen Branchen - Erfahrungen aus Österreich', WSI-Mitteilungen 7: 396-402. 
Holtgrewe, U. (2005) Call Centres in Germany - Preliminary Findings from the Global Call Centre Project - Germany, Universität Duisburg Essen.

Holtgrewe, U. and Kerst, C. (2002) 'Call Center: Die Institutionalisierung von Flexibilität', Industrielle Beziehungen 9(2): 186-208.

Holst, H., Mayer, K. and Feigl-Heihs, M. (2006) 'Atypische Beschäftigung in Call-Centern', in S. Pernicka and A. Aust (eds) Kollektives Erwachen? Gewerkschaftliche Interessenvertretung für atypisch Beschäftigte, pp. 128-92. Vienna: Forschungsbericht.

Hyman, R. (1996) 'Changing Union Identities in Europe', in P. Leisink, J. Van Leemput and J. Vilrokx (eds) The Challenges to Trade Unions in Europe: Innovation or Adaptation, pp. 53-73. Aldershot: Edward Elgar.

Hyman, R. (2001a) 'Trade Union Research and Cross-National Comparisons', European Journal of Industrial Relations 7(2): 203-32.

Hyman, R. (2001b) Understanding European Trade Unionism: Between Market, Class and Society. London: Sage.

Jacobi, O., Keller, B. and Müller-Jentsch, W. (1998) 'Germany: Facing New Challenges', in A. Ferner and R. Hyman (eds) Changing Industrial Relations in Europe, pp. 190-238. Oxford: Blackwell.

Keller, B. (2004) Multibranchengewerkschaft als Erfolgsmodell? Zusammenschlïse als organisatorisches Novum. Hamburg: VSA-Verlag.

Landman, T. (2004) Issues and Methods in Comparative Politics: An Introduction, 2nd edn. London: Routledge.

Lehmbruch, G. and Schmitter, P.C. (1982) Patterns of Corporatist Policymaking. London: Sage.

Locke, R. and Thelen, K. (1995) 'Apples and Oranges Revisited: Contextualized Comparisons and the Study of Comparative Labor Politics', Politics E Society 23(3): 337-57.

OECD (2004) Employment Outlook. Paris: OECD.

March, J.G. and Olsen, J.P. (1994) Ambiguity and Choice. Oslo: Universitetsforlaget.

Martin, A. and Ross, G. (eds) (1999) The Brave New World of European Labor: European Trade Unions at the Millennium. New York: Berghahn.

Pernicka, S. (2005) 'The Evolution of Union Politics for Atypical Employees: A Comparison between German and Austrian Trade Unions in the Private Service Sector', Economic and Industrial Democracy 26(2): 205-28.

Rosner, P. (1999) 'Lohnbewegung und Bewegung der Lohnpolitik', in F. Karlhofer and E. Talos (eds) Zukunft der Sozialpartnerschaft.

Veränderungsdynamik und Reformbedarf, pp. 75-94. Vienna: Signum-Verlag.

Schmidt, R. and Trinczek, R (1999) 'Der Betriebsrat als, Akteur der industriellen Beziehungen', in W. Müller-Jentsch (ed.) Konfliktpartnerschaft. Akteure und Institutionen der industriellen Beziehungen, 3rd edn, pp. 103-28. Munich: Hampp-Verlag.

Schönauer, A. (2005) Qualität der Arbeit in Callcentern. Fallstudie Österreich im Global Call Center Industry Project. Vienna: Forba.

Schregle, J. (1981) 'Comparative Industrial Relations; Pitfalls and Potential', International Labour Review 120: 15-30.

Streeck, W. (1993) 'Klasse, Beruf, Unternehmen, Distrikt: Organisationsgrundlagen industrieller Beziehungen im europäischen Binnenmarkt', in 
B. Strümpel and D. Meinolf (eds) Innovation und Beharrung in der Arbeitspolitik, pp. 39-68. Stuttgart: Schaffer-Poeschel.

Thelen, K. (2002) 'The Political Economy of Business and Labor Revisited in the Developed Democracies', in I. Katznelson and H.V. Milner (eds) Political Science: The State of the Discipline, pp. 371-91. New York: Norton.

Traxler, F. (1998) 'Austria: Still the Country of Corporatism?', in A. Ferner and

R. Hyman (eds) Changing Industrial Relations in Europe, pp. 239-61. Oxford: Blackwell.

Traxler, F. (2001) 'Metamorphosen des Korporatismus. Vom klassischen zum schlanken Muster', Politische Vierteljabresschrift 42: 590-623.

Turner, L. (1991) Democracy at Work. Ithaca, NY: Cornell University Press. Wallerstein, M. (1999) 'Wage-Setting Institutions and Pay Inequality in Advanced Industrial Societies', American Journal of Political Science 43: 649-80.

Weber, M. (1980) Wirtschaft und Gesellschaft. Tübingen: Mohr Siebeck. Williamson, O.E. (1975) Markets and Hierarchies: Analysis and Antitrust Implications. New York: Free Press.

HAJO HOLST teaches European industrial relations at the University of Jena. ADDRESS: Institut für Soziologie, Lehrstuhl für Arbeits-, Industrie- und Wirtschaftssoziologie, Friedrich-Schiller-Universität Jena, Carl-ZeißStraße 2, 07743 Jena, Germany. [e-mail: hajo.holst@uni-jena.de] 